\title{
Developing the Strategic Plans Based on The Analytic Hierarchy Process: The Sample of The Faculty of Architecture of KTU, Trabzon
}

\section{Article History}

Submitted: 10.08 .2020

Accepted: 26.03.2021

Published Online: 30.04.2021

Keywords

SWOT analysis

TOWS matrix

Analytic hierarchy process

Strategic plan

Faculty of Architecture

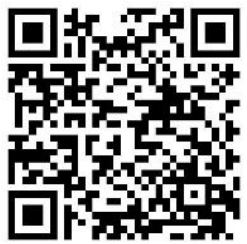

DOI: $10.29129 /$ inujgse. 778648

\author{
Yalçın YAŞAR \\ Karadeniz Technical University, Trabzon - Turkey \\ Sibel MAÇKA KALFA \\ Karadeniz Technical University, Trabzon - Turkey \\ Zeynep PIRSELIMOĞLU BATMAN \\ Bursa Uludag University, Bursa - Turkey \\ Kübra SÜMER HAYDARASLAN \\ Suleyman Demirel University, Isparta - Turkey
}

\section{Abstract}

Purpose: This study, it was aimed to determine the infrastructure main factors (education and training, institutional structure, academic staff, physical and technical) strategies of Karadeniz Technical University Faculty of Architecture.

Design \& Methodology: In the study, strengths and weaknesses, opportunities, and threats of KTU, Faculty of Architecture were determined by using SWOT analysis. The TOWS matrix was created using the data obtained from SWOT analysis. The sample group in the study was composed of faculty members of architecture. Questionnaires rating the main infrastructure factors was applied to this group. These questionnaires were evaluated using the Fuzzy Set technique in connection with the Analytical Hierarchy Process.

Findings: The development strategy planned for the training program at the end of the study is the most appropriate strategy according to the 0.297 importance level. The second priority is to increase national and international research and projects, the third is to expand the academic staff, and the fourth is to eliminate all the deficiencies in the physical environment.

Implications \& Suggestions: Thanks to the strategy and importance levels determined at the end of the study, future steps were determined. Strategic planning is important for the future steps of an organization. This study showed that strategic planning is important. It is important to do like studies in the architecture faculties in Turkey. Thus, differences between institutions can be detected. In addition, the deficiencies can be corrected. 


\title{
Analitik Hiyerarşi Sürecine Bağlı Olarak Stratejik Planların Geliştirilmesi: KTÜ Mimarlık Fakültesi Örneği, Trabzon
}

\author{
Yalçın YAŞAR \\ Karadeniz Teknik Üniversitesi, Trabzon - Türkiye \\ Sibel MAÇKA KALFA \\ Karadeniz Teknik Üniversitesi, Trabzon - Türkiye \\ Zeynep PIRSELIMOĞLU BATMAN \\ Bursa Uludağ Üniversitesi, Bursa - Türkiye \\ Kübra SÜMER HAYDARASLAN \\ Süleyman Demirel Üniversitesi, Isparta - Türkiye
}

Geliş: 10.08 .2020

Kabul: 26.03.2021

Online Yayın: 30.04.2021

Anahtar Sözcükler

SWOT analizi

TOWS matrisi

Analitik hiyerarşi süreci

Stratejik plan

Mimarlık Fakültesi

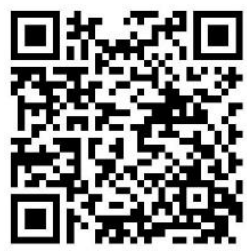

DOI: 10.29129/inujgse. 778648
Öz

Amaç: Çalışma, KTÜ/Mimarlık Fakültesi'nin eğitim-öğretim, kurumsal yapı, akademik kadro ve fiziksel- teknik alt yapı ana faktörler doğrultusunda izlemesi gereken stratejilerin belirlenmesi amacı ile yapılmıştır.

Yöntem: Çalışmada KTÜ/Mimarlık Fakültesinin güçlü ve zayıf yönleri, fırsatlar ve tehditleri SWOT analizi yapılarak belirlenmiştir. SWOT analizinde elde edilen veriler kullanılarak TOWS matrisi oluşturulmuştur. Bu matris vasıtasıyla belirlenen stratejilerden en uygun stratejinin veya stratejilerinin seçilebilmesi için Mimarlık Fakültesi Öğretim Üye/Elemanlarından oluşan 18 kişilik bir örneklem grubundan eğitim-öğretim, kurumsal yapı, akademik kadro ve fiziksel- teknik alt yapı ana faktörlerini ve bu faktörleri oluşturan alt faktörleri nicel olarak önem derecelerine göre karşılaştırmalarına imkan veren bir anketi cevaplamaları istenmiştir. Bu anketler, Analitik Hiyerarşi Sürecine bağıı Fuzzy Set tekniği kullanılarak değerlendirilmiştir.

Bulgular: Yapılan değerlendirme sonucunda; eğitim-öğretim programının planlı gelişimi stratejisi 0,297 önem derecesine göre en uygun strateji olarak belirlenirken, ulusal ve uluslararası araştırma ve projelerin arttırılması ikinci, akademik kadronun genişletilmesi üçüncü ve fiziksel ortamdaki bütün eksikliklerin giderilmesi dördüncü öncelikli strateji olarak belirlenmiştir.

Sonuçlar ve Öneriler: Stratejik planlama kurumun gelişmesini sağlamak için önemli bir role sahiptir. Bu doğrultuda çalışma sonucunda belirlenen strateji ve bunların önem sıralaması doğrultusunda kurumunun geleceği için atılacak adımlar ortaya konmuştur. Stratejik planlamanın önemini gösteren bu pilot çalışma gibi Türkiye'deki diğer mimarlık fakültelerinde de bu şekilde çalışmaların yapılması ve farklılıkların ortaya koyulması önemlidir. Böylelikle aynı eğitimi veren kurumlar arasındaki farklılıklar en aza indirilecektir. 


\section{INTRODUCTION}

Strategic planning is result-oriented initiatives of all personnel in an institution (McCune, 1986). In this context, the needs, mission, and goals of the institution are effective in determining performance criteria. Future strategic planning of an institution; "Where are we now?", "Where do we want to be?", "How can we reach where we want to be?", "How can we determine our roadmap for development?" searches for answers to questions (Steiner, 1989; Aydemir, 2003). Strategic planning studies consist of steps directly affected by each other. Each of these steps needs to be carefully implemented for the success of planning. These steps are shown in Figure 1.

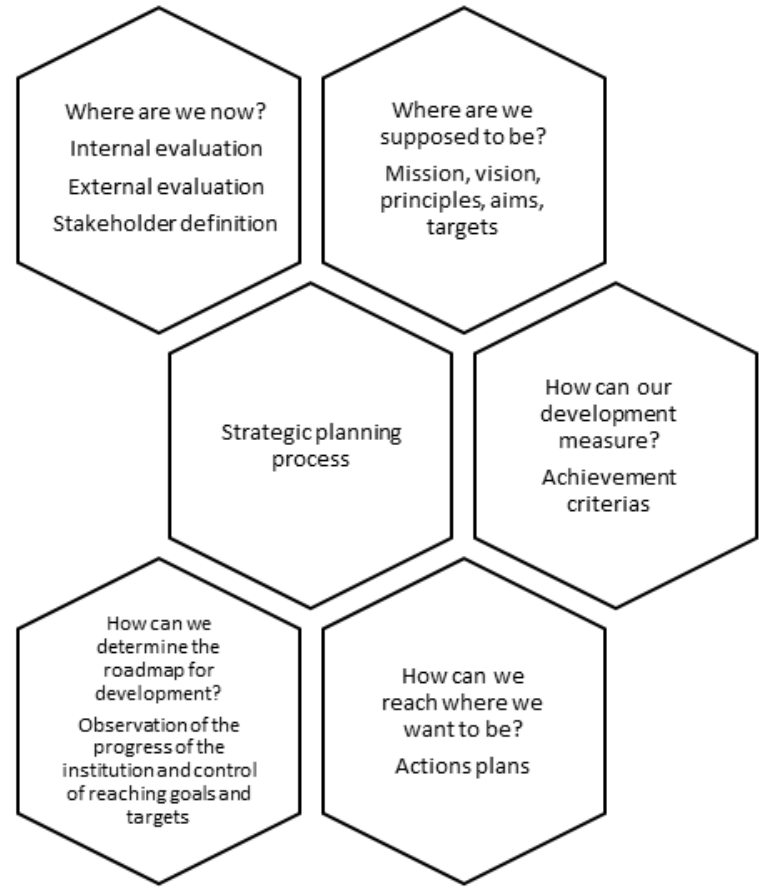

Figure 1. Steps of The Strategic Planning (Steiner, 1989)

The aim of strategic planning is to determine the effective factors in planning. SWOT analysis is utilized to determine these factors (Allison and Kaye, 2015; Dyson et al., 1998). SWOT analysis makes it possible to identify strengths and weaknesses, opportunities, and threats inside and outside an organization (Fine, 2009). It provides information about the institution and does not allow a strategy. Organizing SWOT analysis results as TOWS matrix can create strategies in corporate planning. Strategies are recommended in the TOWS matrix to reinforce the strengths of the organization with the opportunities gained, reduce the organization's vulnerability to external threats, and strengthen its weaknesses (Dyson, 2004). However, the significance levels and strategic decision of the produced strategies and which factor is more influenced cannot be quantitatively evaluated (Shrestha et al., 2004). For these evaluations, the analytical hierarchy process (AHP) which is used to manage multi-criteria decisions, and which is developed by Saaty in 1980 is applied (Saaty, 1980).

Combining AHP and SWOT / TOWS analyses together is better than doing only SWOT / TOWS analyses. SWOT / TOWS analyses do not explain the importance of factors to determine the impact of each factor 
on the plan or strategy. The result of SWOT / TOWS analyses is mostly a list of internal and external environmental factors or an incomplete qualitative review. By using two techniques together, strengths, weaknesses, opportunities, and threats can be known. In addition, these effects can be known based on quantitative AHS prioritization. In addition, by focusing on the weighting of SWOT factors alone, the most important groups cannot be pinpointed (Ho, 2008; Kangas et al., 2003; Shretha, 2004).

Quantitative and qualitative factors are important in the decision-making process of the AHS-fuzzy set technique. In this technique, the needs and expectations of the people involved in the decision-making process are clearly expressed. It can also be directly included in the solution, considering the verbal and numerical values. This technique simplifies complex decision-making problems with its hierarchical structure. In the definition of hierarchy, the purpose should be found at the top, then the criteria that affect the goal, and then the alternatives to be selected. Thanks to the binary comparison, which facilitates the problem by using the technique, the decision maker does not have to list all the alternatives at once. The priority is to determine the importance of one alternative over another (Alford and Golden, 2004). The Analytical Hierarchy Process uses basic mathematics such as addition, multiplication, division. The criteria are also used in the process and determined according to the importance of the decision maker. Then the preference table is prepared. Table 4 contains the values given by the decision maker for the criteria (Saaty, 1980).

Table 2

AHP Standard Value Table (Saaty, 1980)

\begin{tabular}{c|l}
\multicolumn{1}{c|}{ Significance levels } & \multicolumn{1}{c}{ Value definitions } \\
\hline 1 & Equally important \\
\hline 3 & A little more important (less superiority) \\
\hline 5 & Quite important (much superiority) \\
\hline 7 & Very important (much superiority) \\
\hline 9 & Extremely important (Precise superiority) \\
\hline $2,4,6,8$ & Intermediate values (Values of reconciliation) \\
\hline
\end{tabular}

\section{Purpose and Importance of the Research}

Today, many institutions use the SWOT / TOWS analyses technique and the AHS technique for their future studies. With these techniques, the importance of institution strategies can be determined. It is important to use these techniques for strategic planning in university faculties. For this reason, Karadeniz Technical University, Faculty of Architecture was investigated in this study. The strategic planning of the faculty of architecture was created using the SWOT / TOWS analyses technique and the AHS technique. In addition, a roadmap for the future strategies of the faculty was drawn.

\section{Karadeniz Technical University; Faculty of Architecture}

The architecture faculty examined in the study is in Karadeniz Technical University. The faculty consists of architecture, interior architecture, city, and region planning departments. 5 professors, 18 associate professors, 17 assistant professors, 8 lecturers and 32 research assistants work in the faculty. A total of 1064 students continue their education, including 499 students in the architecture department, 319 students in the department of interior architecture, and 224 students in the city and regional planning department. The number of students has increased in recent years. This situation caused a lack of physical space in the faculty. For this reason, the city and regional planning department is in a separate 
building. Internal stakeholders of the faculty are university administration, dean, academic staff, administrative staff, and students. External stakeholders of the faculty are the other faculties' departments, professional chambers, public and private organizations, former academic staff, administrative staff, student associations. The faculty continuously communicates with internal and external stakeholders. The opinions of internal and external stakeholders are considered in the planning of the faculty. Architecture faculty building is given in Figure 2.

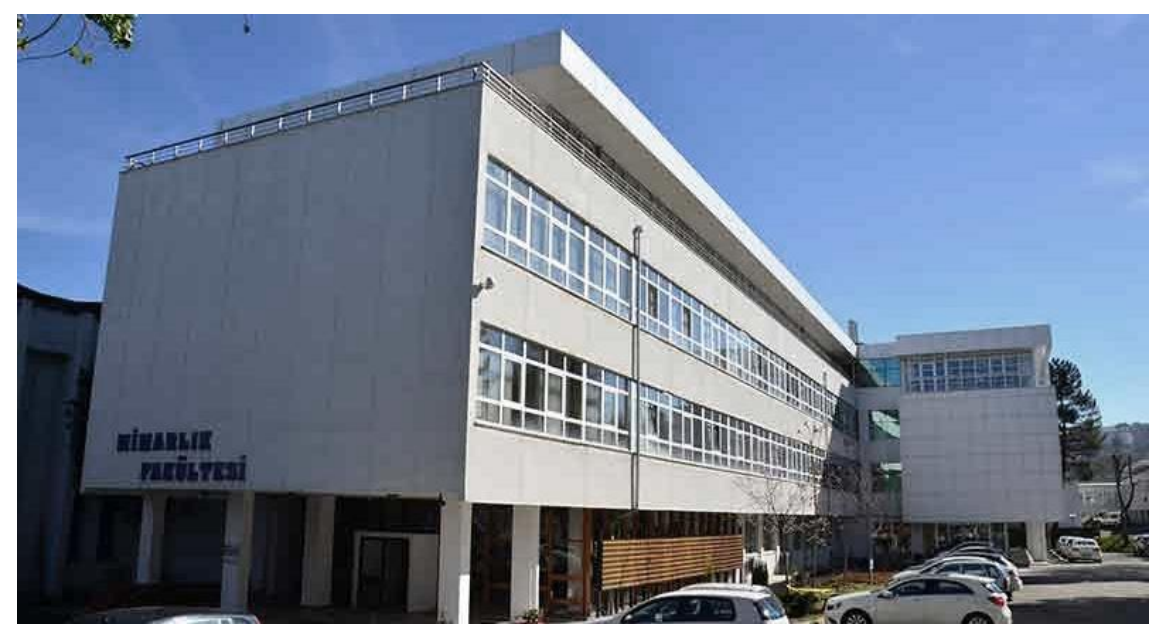

Figure 2. The Faculty of Architecture

METHOD

\section{Pattern}

Within the scope of the study, the current situation, mission-vision, internal and external stakeholders principles, goals and objectives of the faculty were examined. At the end of the examination, the strengths and weaknesses, opportunities and threats of the faculty were determined by using a SWOT analysis. TOWS matrix was created by using SWOT analysis. With the matrix, the current situation (strengths, weaknesses, opportunities, and threats) of the faculty is evaluated with its mission and vision. Later, answers to "How can internal and external weaknesses be reduced?" and "How can opportunities be turned into power?" questions were presented.

\section{Participants / Universe and Sample / Working Group}

Strategies were determined with the answers received. To evaluate these strategies, 18 faculty members, including 4 professors, 5 associate professors, 5 assistant professors, 2 lecturers and 3 research assistants, were asked to respond to the questionnaires prepared by experts. The questionnaires were evaluated by using the Fuzzy Set technique based on the analytic hierarchy process. In Figure 3, the chart of workflow followed in the study is shown. 


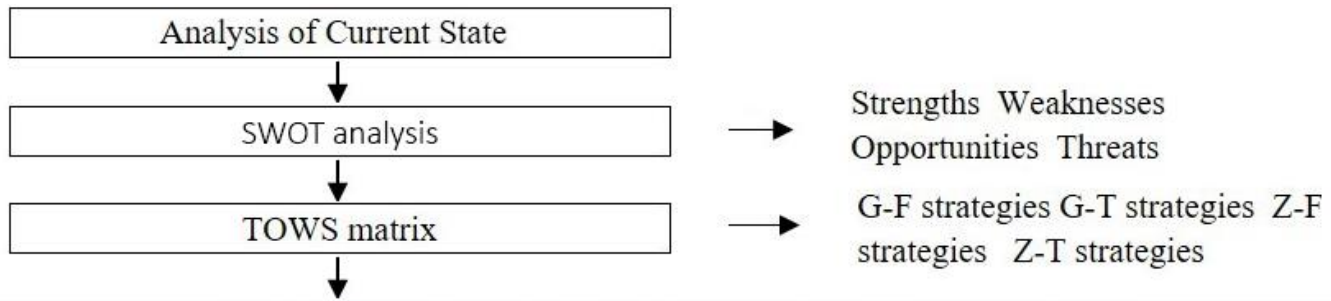

Evaluation of the questionnaire results (Analytic hierarchy process)

Determination of the most appropriate strategy or strategies

Figure 3. The Workflow Chart

Data Collection Tools

\section{Survey}

A questionnaire was prepared to evaluate the determined strategies. This questionnaire was applied to 18 faculty members, including 4 professors, 5 associate professors, 5 assistant professors, 2 lecturers, and 3 research assistants. We paid attention that the participants had different titles. The questionnaires were evaluated by using the Fuzzy Set technique based on the analytical hierarchy process.

\section{The Analytic Hierarchy Process (AHP-Fuzzy Set Technique)}

Four main factors (education, institutional structure, academic staff, physical and technical infrastructure) formed by SWOT analysis were determined in the questionnaires. Using analytical hierarchy process targets and binary comparison matrices, a questionnaire was created based on 5 training, 4 institutional structures, 4 academic staff, and 4 physical and technical infrastructures.

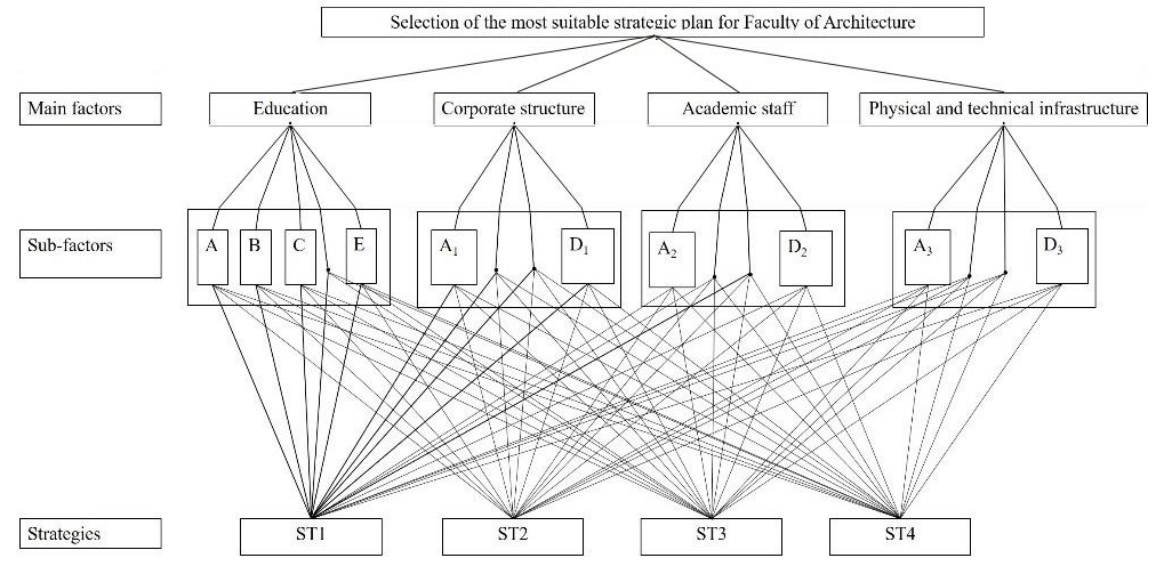

Figure 4. The process followed in determining the most appropriate strategy / strategies for the strategic plan of the faculty of architecture. 
These matrices were evaluated according to the answers given by the participants. In addition to the matrices calculated by the geometric averages of the points given by the participant group to the questions in the paired comparison questionnaires, the weighting points of the strategies according to these factors were also determined for the weighting points of each sub-factor. Main factors and the sub-factors that make up these main factors are given in Table 2.

Table 2

Main factors and sub-factors

\begin{tabular}{|c|c|c|c|c|}
\hline & \multicolumn{2}{|r|}{ Corporate structure } & Academic Staff & $\begin{array}{l}\text { Physical and Technical } \\
\text { Infrastructure }\end{array}$ \\
\hline $\mathrm{A}$ & $\begin{array}{l}\text { Updating / revising education } \\
\text { program for equivalence with } \\
\text { other universities }\end{array}$ & $\begin{array}{l}\text { Providing domestic/overseas } \\
\text { internship, Erasmus, Leonardo } \\
\text { etc. working partnerships and } \\
\text { summer school facilities }\end{array}$ & $\begin{array}{l}\text { Strengthening academic staff } \\
\text { with specialized academicians }\end{array}$ & $\begin{array}{l}\text { Providing workshops for } \\
\text { students' designing studies }\end{array}$ \\
\hline B & Not increasing student quota & $\begin{array}{l}\text { Strengthening international } \\
\text { collaborations and research }\end{array}$ & $\begin{array}{l}\text { Increasing the number of } \\
\text { research assistants }\end{array}$ & $\begin{array}{l}\text { Updating the general } \\
\text { equipment required for the } \\
\text { location of education }\end{array}$ \\
\hline C & $\begin{array}{l}\text { Taking the opinions of the } \\
\text { student representative and } \\
\text { hence the students during } \\
\text { decision-making process in } \\
\text { the education }\end{array}$ & $\begin{array}{l}\text { Strengthening the } \\
\text { relationships with other } \\
\text { universities and research } \\
\text { institutions }\end{array}$ & $\begin{array}{l}\text { Assigning teaching members } \\
\text { from different departments }\end{array}$ & $\begin{array}{l}\text { Removing shortages of } \\
\text { building for the Department of } \\
\text { Urban and Regional Planning }\end{array}$ \\
\hline $\mathrm{D}$ & $\begin{array}{l}\text { Making joint education } \\
\text { activities (strong student- } \\
\text { academic relationship) }\end{array}$ & $\begin{array}{l}\text { Strengthening communication } \\
\text { with local administrations }\end{array}$ & $\begin{array}{l}\text { Conducting joint academic } \\
\text { work }\end{array}$ & $\begin{array}{l}\text { Creating opportunities to } \\
\text { archive in the faculty and } \\
\text { create database }\end{array}$ \\
\hline $\mathrm{E}$ & $\begin{array}{l}\text { To invite experts from } \\
\text { different disciplines to help } \\
\text { students with their courses so } \\
\text { that they can increase their } \\
\text { knowledge. }\end{array}$ & & & \\
\hline
\end{tabular}

Following the SWOT analysis and the TOWS matrix, 4 strategies were identified, and the appropriateness of these strategies was obtained by evaluating the questionnaires. Strategies which were identified are given below

ST1.Planning the development of the educational program

ST2.Increasing national and international research and projects

ST3.Increasing the number of academic staff

ST4.Elimination of all deficiencies in the physical environment

\section{Data Analysis}

In this section, the strengths and weaknesses, opportunities, and threats for the faculty of architecture have been identified in terms of four main factors written in the following articles. The data for the SWOT analysis have been given in Table 3 .

1.Education

2.Corporate structure

3.Academic staff

4.Physical and technical infrastructure 
Table 3

SWOT analysis

\begin{tabular}{|c|c|c|c|c|}
\hline $\begin{array}{l}\text { Main } \\
\text { Factors }\end{array}$ & Strengths & Weaknesses & Opportunities & Threats \\
\hline Education & $\begin{array}{l}\text { - The existence of a rooted } \\
\text { educational tradition and } \\
\text { the updatability } \\
\text { - Proximity to EU } \\
\text { architectural norms as } \\
\text { student-focused in } \\
\text { education } \\
\text { - Strong communication } \\
\text { between students and } \\
\text { academics } \\
\text { - Young staff with } \\
\text { pedagogical training } \\
\text { - Interdisciplinary } \\
\text { information flow } \\
\text { - Post-graduate education } \\
\text { (master and doctorate) and } \\
\text { double major / minor } \\
\text { programs } \\
\text { - International } \\
\text { communication programs } \\
\text { - The level of education and } \\
\text { the quality of the students } \\
\text { raised } \\
\text { - Student clubs } \\
\text { - Traditional activities of the } \\
\text { faculty and each } \\
\text { department } \\
\text { (exhibition/seminar, } \\
\text { conferences, etc.) }\end{array}$ & $\begin{array}{l}\text { - Inadequacy of academic } \\
\text { and administrative staff } \\
\text { - Lack of programs to } \\
\text { strengthen the socio- } \\
\text { cultural aspects of students } \\
\text { - Inadequacy of graduate } \\
\text { lectures } \\
\text { - Inadequacy of social } \\
\text { counseling services } \\
\text { - Lack of doctoral programs } \\
\text { in two departments within } \\
\text { the faculty (Interior } \\
\text { Architecture-DURP) } \\
\text { - Lack of vocational training } \\
\text { - Archiving system is not } \\
\text { professional and systematic } \\
\text { - Inadequacy of foreign } \\
\text { connections } \\
\text { - Insufficient use of distance } \\
\text { training facilities } \\
\text { - Lack of a peer-reviewed } \\
\text { journal }\end{array}$ & $\begin{array}{l}\text { - The importance of faculty } \\
\text { of architecture in the region } \\
\text { - The popularity of } \\
\text { education and the } \\
\text { profession, the abundance } \\
\text { of graduates' employment } \\
\text { options, especially in big } \\
\text { cities } \\
\text { - The region has potential } \\
\text { for education and research, } \\
\text { the opportunity to make } \\
\text { corporate cooperation with } \\
\text { local governments } \\
\text { - National and international } \\
\text { relations that are growing } \\
\text { stronger } \\
\text { - Attaining the expected } \\
\text { efficiency of laboratories } \\
\text { - Providing continuity and } \\
\text { tradition in national- } \\
\text { international congresses } \\
\text { - The education program } \\
\text { includes items to } \\
\text { strengthen the "Social } \\
\text { Responsibility" } \\
\text { - The region's tourism } \\
\text { potential } \\
\text { - Vocational training } \\
\text { capacity }\end{array}$ & $\begin{array}{l}\text { - Increasing student quota } \\
\text { - The distance of the } \\
\text { university to the national } \\
\text { student pool due to its } \\
\text { geographical location } \\
\text { - Private university in the } \\
\text { city } \\
\text { - The region is introverted } \\
\text { - The fact that a significant } \\
\text { proportion of the students } \\
\text { come from the region limits } \\
\text { the socio-cultural diversity } \\
\text { among students } \\
\text { - Competition among } \\
\text { universities in big cities and } \\
\text { in western regions } \\
\text { - Lack of interest and } \\
\text { participation in practices } \\
\text { and the city, inadequacy of } \\
\text { demand } \\
\text { - The faculty is ineffective in } \\
\text { architecture and planning in } \\
\text { the city and the region due } \\
\text { to the inadequacy of its } \\
\text { revolving funds }\end{array}$ \\
\hline
\end{tabular}

Table 3 indicates the internal strengths and weaknesses of the faculty of architecture and the opportunities and threats that arise from external factors. In this way, strategies for the future have been identified by analysing the strengths and weaknesses along with the opportunities and threats of the faculty while planning.

\section{TOWS Matrix}

As a result of analysing the internal and external factors of the system considering the data obtained from the SWOT analysis, the TOWS matrix was developed for a strategic view. How the TOWS matrix was developed is given in Table 4. Accordingly, the first column of the matrix indicates the opportunities and threats related to the system determined at the first stage of the SWOT analysis, while the first line indicates the strengths and weaknesses of the system obtained at the same stage.

The answer to the "What should be done so that the internal-external weaknesses of the institution can be reduced, and opportunities can be turned into difficulties?" question was evaluated within the framework of "Strategy Development Matrix (TOWS)", taking into account what is given in Table 2 and evaluating the current situation of the faculty. This TOWS Matrix was created by using the results obtained from SWOT analysis and has been given in Table 5. 
Table 4

TOWS matrix (Weihrich, 1982)

\begin{tabular}{c|l|l}
\multicolumn{2}{|c}{ Strengths } \\
Opportunities & $\begin{array}{l}\bullet \text { G-F Strategies } \\
\text { identify and assess opportunities that support } \\
\text { the strengths of the system }\end{array}$ & $\begin{array}{l}\bullet \text { Z-F Strategies } \\
\text { strategies developed using opportunities to remove } \\
\text { weaknesses }\end{array}$ \\
\hline \multirow{2}{*}{ Threats } & $\begin{array}{l}\bullet \text { G-T strategies } \\
\text { reveal how the system's strengths should be } \\
\text { used to reduce the vulnerability of the system } \\
\text { to external threats }\end{array}$ & $\begin{array}{l}\bullet \text { Z-T strategies } \\
\text { prepare defense plans that will prevent vulnerabilities } \\
\text { of the system from being easily affected by external } \\
\text { threats }\end{array}$ \\
\hline
\end{tabular}

Table 5

TOWS matrix

\begin{tabular}{|c|c|c|}
\hline \multicolumn{2}{|r|}{ Strengths } & Weaknesses \\
\hline Opportunities & $\begin{array}{l}\text { - G-F } 1 \text {. To evaluate the dynamism and capacity of the } \\
\text { academic staff in the research / implementation } \\
\text { projects. } \\
\text { Thus; it is expected that } \\
\text { The theoretical and practical learning of the students } \\
\text { will be improved together } \\
\text { The skills of students, especially the academic staff } \\
\text { will be improved by trying new techniques / } \\
\text { approaches, sharing experiences on national / } \\
\text { international platforms } \\
\text { Resources will be created and the faculty will be self- } \\
\text { sufficient. } \\
\text { - G-F } 2 \text {. Creating and sustaining vocational training } \\
\text { programs } \\
\text { To adapt the knowledge and skill level of the } \\
\text { workforce in the region to the changing conditions } \\
\text { and technologies of the day and increase the indirect } \\
\text { economic contribution of the KTU to the region } \\
\text { through departments } \\
\text { These studies can be carried out either by developing } \\
\text { one of the existing research centers or by establishing } \\
\text { a new center. } \\
\text { - G-F } 3 \text {. To provide cooperation with local } \\
\text { governments and non-governmental organizations, } \\
\text { identify general and specific problem areas and } \\
\text { priorities, establish a regional database }\end{array}$ & $\begin{array}{l}\text { - Z-F } 1 \text {. To strengthen the academic staff quantitatively and } \\
\text { qualitatively } \\
\text { - Z-F } 2 \text {. To prepare interactive environments for the staff that } \\
\text { will participate in international projects } \\
\text { - Z-F } 3 \text {. To publish an "Architectural Bulletin" in the Faculty } \\
\text { - Z-F } 4 \text {. To develop and implement "social responsibility" } \\
\text { projects for students within the scope of education. } \\
\text { Thus; it is expected } \\
\text { To ensure that the faculty is publicly recognized at the local and } \\
\text { national level, } \\
\text { To develop a sense of belonging to the institution / city / region } \\
\text { by creating a team spirit among the students, } \\
\text { To generate opportunities for students who will probably be } \\
\text { coming from the region and neighbouring regions to develop } \\
\text { themselves socially. } \\
\text { - Z-F 5. To take precautions to balance the time that } \\
\text { academicians will allocate for academic work, to expand the } \\
\text { number of instructors that will lecture in the medium to long- } \\
\text { term. For this; } \\
\text { Inviting faculty members from other universities, } \\
\text { And/or benefiting from the newly created distance learning } \\
\text { opportunities in the university } \\
\text { - Z-F } 6 \text {. To establish relationships in various forms with } \\
\text { domestic universities in order to enhance the experience of the } \\
\text { academic staff } \\
\text { Thus; it is expected } \\
\text { To try to transfer faculty members reciprocally } \\
\text { To send departmental staff to other universities for one } \\
\text { semester, or } \\
\text { To invite lecturers from other universities and assign them to } \\
\text { undergraduate and graduate courses }\end{array}$ \\
\hline Threats & $\begin{array}{l}\text { - G-T 1. To reduce the negative effects of } \\
\text { geographical location by establishing national and } \\
\text { international connections (student and teaching staff } \\
\text { transfers, congress, summer school, etc.) } \\
\text { - G-T 2. To reach all the teaching staff and their work } \\
\text { in electronic environment, increase international and } \\
\text { national scale relations and recognition }\end{array}$ & $\begin{array}{l}\text { - Z-T 1. To insist on bringing student quotas to a level that will } \\
\text { increase the quality of education }\end{array}$ \\
\hline
\end{tabular}




\section{BULGULAR}

\section{Comparison of The Main Factors}

As a result of the survey conducted for the Faculty of Architecture, education, and training (0.410) was the most important main factor. It was followed by corporate structure, academic staff, and physical and technical infrastructure respectively (Table 6). Figure 5 indicates the significance levels of the main factors.

Table 6

Matrix of main factors

\begin{tabular}{|c|c|c|c|c|c|}
\hline & Education & $\begin{array}{l}\text { Corporate } \\
\text { structure }\end{array}$ & Academic staff & $\begin{array}{l}\text { Physical and technical } \\
\text { infrastructure }\end{array}$ & $\begin{array}{l}\mu \text { main } \\
\text { factors }\end{array}$ \\
\hline Education & 1 & 2 & 2 & 3 & 0.410 \\
\hline Corporate structure & & 1 & 3 & 2 & 0.301 \\
\hline Academic staff & & & & 2 & 0.171 \\
\hline Physical and technical infrastructure & & & & 1 & 0.118 \\
\hline
\end{tabular}

\section{Comparison of Education Sub-Factors and Strategies}

The statistical values obtained from the questionnaire evaluations under the heading of education factors and strategies have been presented in Table 7. Figure 6 shows the comparison of the significance ratings of the education sub-factors. Referring to Figure 6 , because of the comparison of sub-factors $A$, $B, C, D, E$ within the scope of education main factor A (updating/revising the education program for equivalence with other universities) was identified as the most important sub-factor with 0.458 . B (not increasing the student quota) sub-factor was second with a value of 0.212 . When the educational strategies of the faculty are compared, the participants were asked which strategy was more appropriate considering the updating / revising the education program for equivalence with other universities (A). ST 1 the planned development of education program was identified as the most appropriate strategy with 0.404 . When considering not increasing student quota (B), the participants answered the question which strategy is more appropriate with ST 4. Elimination of all the deficiencies in the physical environment with 0.361 value. When considering taking the opinion of the student representative, hence the students during the decision-making process (C), ST 1. the planned development of the education program was identified as the most appropriate strategy.

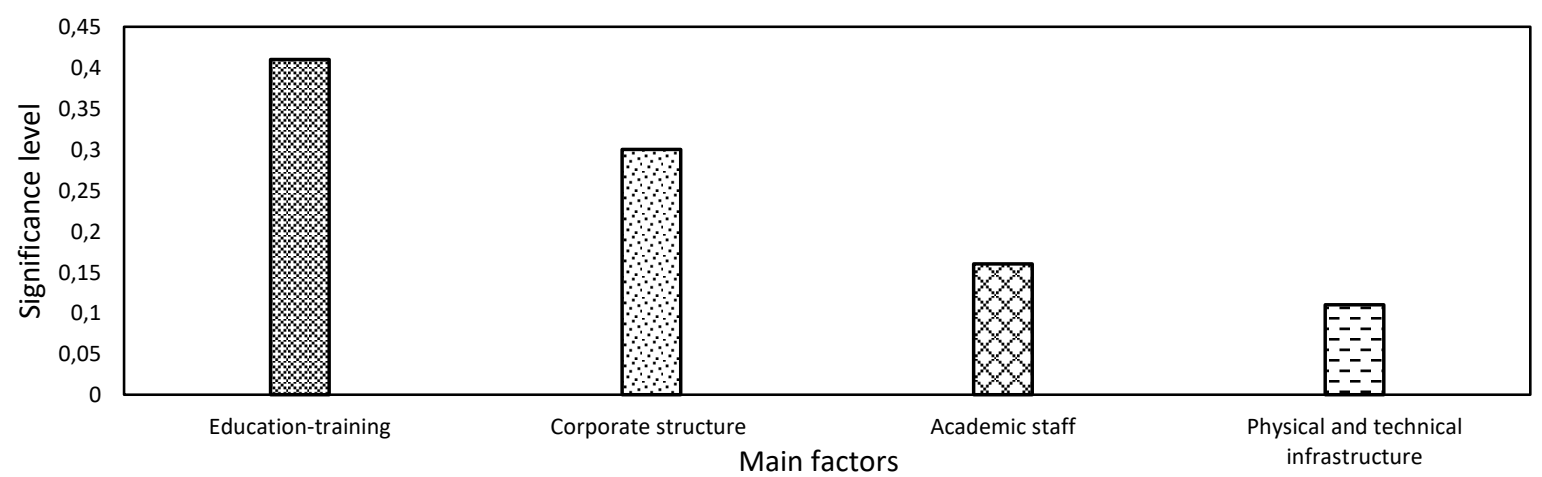

Figure 5. The significance levels of the main factors 
Table 7

Comparison of education factors and strategies

\begin{tabular}{|c|c|c|c|c|c|c|c|c|}
\hline \multirow{6}{*}{\multicolumn{2}{|c|}{ Education sub-factors matrix }} & & A & B & C & $\mathrm{D}$ & $\mathrm{E}$ & $\mu$ \\
\hline & & A & 1 & 5 & 3 & 3 & 4 & 0.458 \\
\hline & & B & & 1 & 3 & 2 & 3 & 0.212 \\
\hline & & C & & & 1 & 3 & 4 & 0.167 \\
\hline & & D & & & & 1 & 3 & 0.106 \\
\hline & & $E$ & & & & & 1 & 0.057 \\
\hline \multirow{5}{*}{\multicolumn{2}{|c|}{ Matrix of strategies according to $A$}} & & ST1 & ST2 & ST3 & ST4 & & \\
\hline & & ST1 & 1 & 0.333 & 0.5 & 0.5 & & 0.404 \\
\hline & & ST2 & & 1 & 3 & 1 & & 0.136 \\
\hline & & ST3 & & & 1 & 2 & & 0.222 \\
\hline & & ST4 & & & & 1 & & 0.238 \\
\hline \multirow{4}{*}{\multicolumn{2}{|c|}{ Matrix of strategies according to $B$}} & ST1 & 1 & 0.333 & 2 & 1 & & 0.264 \\
\hline & & ST2 & & 1 & 1 & 0.5 & & 0.145 \\
\hline & & ST3 & & & 1 & 3 & & 0.230 \\
\hline & & ST4 & & & & 1 & & 0.361 \\
\hline \multirow{4}{*}{\multicolumn{2}{|c|}{ Matrix of strategies according to $C$}} & ST1 & 1 & 0.5 & 0.5 & 0.5 & & 0.4 \\
\hline & & ST2 & & 1 & 1 & 1 & & 0.2 \\
\hline & & ST3 & & & 1 & 1 & & 0.2 \\
\hline & & ST4 & & & & 1 & & 0.2 \\
\hline \multirow{4}{*}{\multicolumn{2}{|c|}{ Matrix of strategies according to $D$}} & ST1 & 1 & 0.2 & 3 & 0.5 & & 0.336 \\
\hline & & ST2 & & 1 & 1 & 0.333 & & 0.198 \\
\hline & & ST3 & & & 1 & 1 & & 0.329 \\
\hline & & ST4 & & & & 1 & & 0.138 \\
\hline \multirow{4}{*}{\multicolumn{2}{|c|}{ Matrix of strategies according to $E$}} & ST1 & 1 & 0.2 & 0.5 & 0.5 & & 0.459 \\
\hline & & ST2 & & 1 & 1 & 1 & & 0.16. \\
\hline & & ST3 & & & 1 & 1 & & 0.190 \\
\hline & & ST4 & & & & 1 & & 0.190 \\
\hline \multirow{6}{*}{ General Education Matrix } & & A & B & C & $\mathrm{D}$ & $\mathrm{E}$ & EigenVector & Product \\
\hline & ST1 & 0.404 & 0.264 & 0.4 & 0.336 & 0.459 & 0.458 & 0.367 \\
\hline & ST2 & 0.136 & 0.145 & 0.2 & 0.198 & 0.16 & 0.212 & 0.154 \\
\hline & ST3 & 0.222 & 0.230 & 0.2 & 0.329 & 0.190 & 0.167 & 0.226 \\
\hline & ST4 & 0.238 & 0.361 & 0.2 & 0.138 & 0.190 & 0.106 & 0.242 \\
\hline & & & & & & & 0.057 & \\
\hline
\end{tabular}

Considering conducting joint educational activities (strong student-academic relationship) (D), while ST1 the planned development of the education program was the most appropriate strategy with 0.336 , ST3 Increasing the number of academic staff was the second most appropriate strategy with 0.329 . Considering $(E)$ the invitation of experts from different disciplines to increase the knowledge of the students, ST1 the planned development of the education program was determined as the most appropriate strategy with 0.459 .

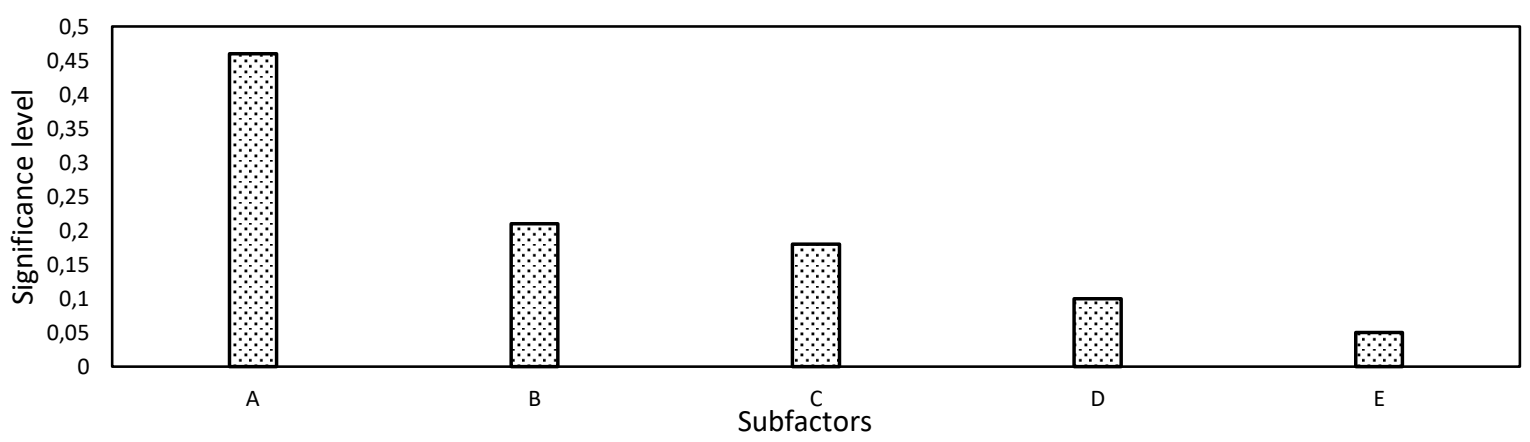

Figure 6. The comparison of the significance ratings of the education sub-factors 
As a result of the comparison of educational factors, it was determined that the most appropriate strategy was ST 1 (the planned development of the education program) with 0.367 . ST1 is followed by ST4 (elimination of all deficiencies in the physical environment) with 0.242 .

\section{Comparison of Corporate Structure Sub-Factors and Strategies}

The comparison results of the sub-factors A, B, C, D in the main factor of corporate structure is given in Figure 7. $C$ (Strengthening relations with other universities and research institutes) was determined as the most appropriate factor with 0.350 value. D (strengthening communication with local administrations) was the second most appropriate sub-factor with 0.322 . Table 8 shows the statistical values resulting from the comparison of corporate structures and strategies.

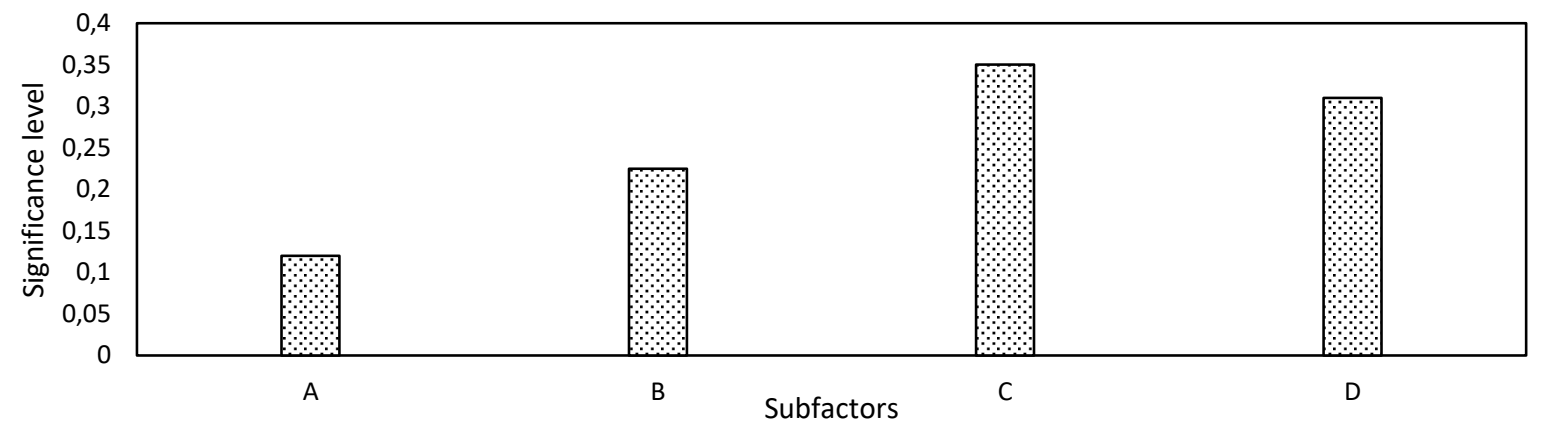

Figure 7. The comparison results of the sub-factors $A, B, C, D$

Table 8

Comparison of corporate structure factors and strategies

\begin{tabular}{|c|c|c|c|c|c|c|c|}
\hline & & A & B & C & $\mathrm{D}$ & $\mu$ \\
\hline \multirow{4}{*}{\multicolumn{2}{|c|}{ Matrix of corporate structure sub-factors }} & A & 1 & 3 & 3 & 2 & 0.112 \\
\hline & & B & & 1 & 2 & 2 & 0.216 \\
\hline & & $\mathrm{C}$ & & & 1 & 1 & 0.350 \\
\hline & & $\mathrm{D}$ & & & & 1 & 0.322 \\
\hline \multirow{5}{*}{\multicolumn{2}{|c|}{ Matrix of strategies according to $A$}} & & ST1 & ST2 & ST3 & ST4 & \\
\hline & & ST1 & 1 & 2 & 0.5 & 0.5 & 0.244 \\
\hline & & ST2 & & 1 & 0.24 & 0.2 & 0.518 \\
\hline & & ST3 & & & 1 & 1 & 0.122 \\
\hline & & ST4 & & & & 1 & 0.116 \\
\hline \multirow{4}{*}{\multicolumn{2}{|c|}{ Matrix of strategies according to $B$}} & ST1 & 1 & 4.0 & 0.33 & 0.33 & 0.238 \\
\hline & & ST2 & & 1 & 0.25 & 0.25 & 0.559 \\
\hline & & ST3 & & & 1 & 1 & 0.102 \\
\hline & & ST4 & & & & 1 & 0.102 \\
\hline \multirow{4}{*}{\multicolumn{2}{|c|}{ Matrix of strategies according to $C$}} & ST1 & 1 & 5.0 & 0.333 & 0.333 & 0.214 \\
\hline & & ST2 & & 1 & 0.2 & 0.25 & 0.598 \\
\hline & & ST3 & & & 1 & 1 & 0.090 \\
\hline & & ST4 & & & & 1 & 0.097 \\
\hline \multirow{4}{*}{\multicolumn{2}{|c|}{ Matrix of strategies according to $D$}} & ST1 & 1 & 4.0 & 0.5 & 0.333 & 0.232 \\
\hline & & ST2 & & 1 & 0.333 & 0.333 & 0.522 \\
\hline & & ST3 & & & 1 & 1 & 0.128 \\
\hline & & ST4 & & & & 1 & 0.119 \\
\hline \multirow{5}{*}{ General corporate structure matrix } & & A & $\mathrm{B}$ & $\mathrm{C}$ & $\mathrm{D}$ & Eigen vector & Product \\
\hline & ST1 & 0.244 & 0.238 & 0.214 & 0.232 & 0.112 & 0.226 \\
\hline & $\mathrm{ST} 2$ & 0.518 & 0.559 & 0.598 & 0.522 & 0.216 & 0.555 \\
\hline & ST3 & 0.122 & 0.102 & 0.090 & 0.128 & 0.350 & 0.107 \\
\hline & ST4 & 0.116 & 0.102 & 0.097 & 0.119 & 0.322 & 0.103 \\
\hline
\end{tabular}


The participants were asked which strategy would be more appropriate considering providing domestic/overseas internship, Erasmus, Leonardo etc. working partnerships and summer school facilities (A). The most important strategy was identified as ST2 (increasing the number of national and international research and projects) with 0.518 value. Also, the most appropriate strategy for the strengthening of international cooperation and research (B) was determined as ST2 (increasing national and international research and projects) with 0.559 value. The planned development of the education program (ST 1) was determined as the second most appropriate strategy. The most appropriate method for strengthening relations with other universities and research institutes (C) was designated as ST 2 (increasing the number of national and international research and projects) with a value of 0.598 . When the sub-factor (D) of strengthening communication with local administrations is evaluated, ST 2 (increasing national and international research and projects) was determined as the most appropriate strategy with a value of 0.522 . As a result of the comparison of corporate structure factors, ST 2 (increasing national and international research and projects) was identified as the most appropriate strategy with a value of 0.555 . ST 1 (planned development of the education program) was identified as the second most appropriate strategy with a value of 0.226 .

\section{Comparison of Academic Staff Factors and Strategies}

The comparison results of the sub-factors A, B, C, D in the main factor of the academic staff is given in Figure 8 . When Figure 8 is examined, $D$ (conducting common academic studies) was identified as the most appropriate factor. Assigning teaching members from different departments (C) was determined as the second most appropriate sub-factor with a value of 0.292 .

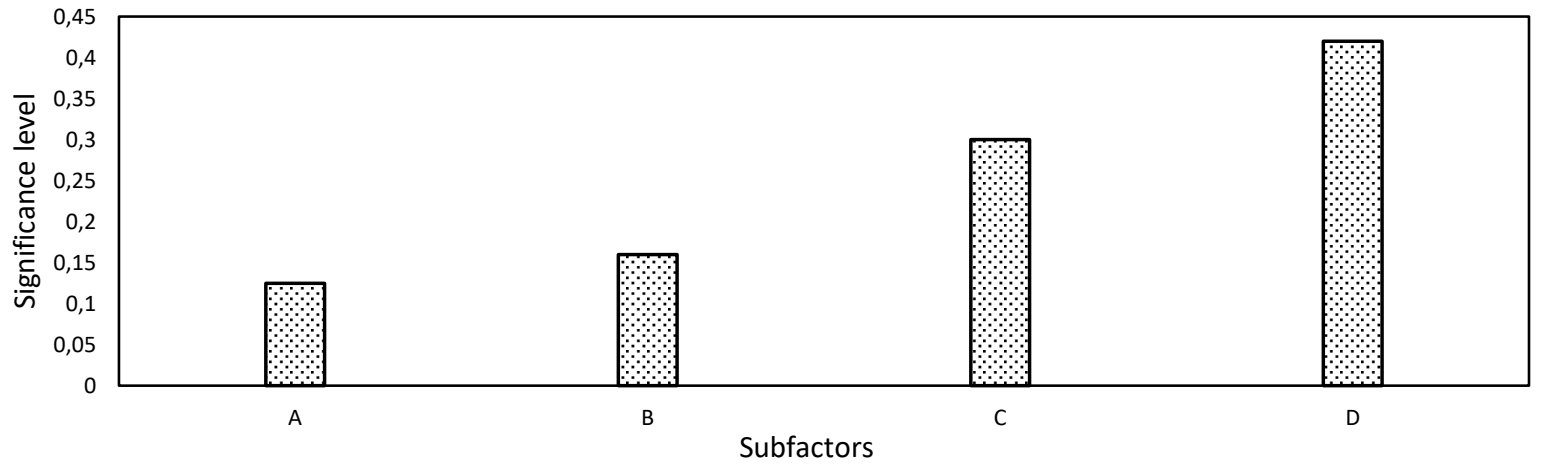

Figure 8. The comparison results of the sub-factors $A, B, C, D$

When the statistical values of the results of comparing the academic staffs and strategies in Table 9 are examined, the most appropriate strategy for the sub-factor of strengthening the academic staff with specialized academicians (A) was determined as ST3 (increasing the number of academic staff) with a value of 0.616. For the sub-factor of increasing the number of research assistants (B), ST3 (increasing the number of academic staff) was found to be the most appropriate strategy with a value of 0.594 . For the sub-factor of assigning teaching members from different departments (C), ST1 (planned development of the education) was found to be the most appropriate strategy with a value of 0.502 . For the sub-factor of conducting joint academic work (D), ST1 (planned development of the education-training program) was determined as the most appropriate strategy with a value of 0.455 . ST 2 (increasing the number of national and international research and projects) was determined as the second-best strategy with a value of 0.275 . The comparison of the academic staff factors showed that ST 1 is the most appropriate 
(the planned development of the education program) with 0.395 . With a value of 0.262 , ST3 (increasing the number of academic staff) was the second most appropriate strategy.

Table 9

Comparison of corporate structure factors and strategies

\begin{tabular}{|c|c|c|c|c|c|c|c|}
\hline \multirow{5}{*}{\multicolumn{2}{|c|}{ Matrix of academic staff sub-factors }} & & A & B & C & D & $\mu$ \\
\hline & & A & 1 & 2 & 3 & 2 & 0.117 \\
\hline & & $\mathrm{B}$ & & 1 & 3 & 2 & 0.163 \\
\hline & & C & & & 1 & 3 & 0.292 \\
\hline & & $\mathrm{D}$ & & & & 1 & 0.428 \\
\hline \multirow{5}{*}{\multicolumn{2}{|c|}{ Matrix of strategies according to $\mathrm{A}$}} & & ST1 & ST2 & ST3 & ST4 & \\
\hline & & ST1 & 1 & 0.333 & 5 & 0.5 & 0.192 \\
\hline & & ST2 & & 1 & 5 & 1 & 0.092 \\
\hline & & ST3 & & & 1 & 0.2 & 0.616 \\
\hline & & ST4 & & & & 1 & 0.100 \\
\hline \multirow{4}{*}{\multicolumn{2}{|c|}{ Matrix of strategies according to $B$}} & ST1 & 1 & 0.333 & 4 & 0.5 & 0.208 \\
\hline & & ST2 & & 1 & 5 & 1 & 0.095 \\
\hline & & ST3 & & & 1 & 0.2 & 0.594 \\
\hline & & ST4 & & & & 1 & 0.103 \\
\hline \multirow{4}{*}{\multicolumn{2}{|c|}{ Matrix of strategies according to $C$}} & ST1 & 1 & 0.2 & 0.333 & 0.5 & 0.502 \\
\hline & & ST2 & & 1 & 2 & 1 & 0.117 \\
\hline & & ST3 & & & 1 & 0.5 & 0.227 \\
\hline & & ST4 & & & & 1 & 0.154 \\
\hline \multirow{4}{*}{\multicolumn{2}{|c|}{ Matrix of strategies according to $D$}} & ST1 & 1 & 0.333 & 0.333 & 0.5 & 0.455 \\
\hline & & ST2 & & 1 & 0.25 & 0.5 & 0.275 \\
\hline & & ST3 & & & 1 & 2 & 0.096 \\
\hline & & ST4 & & & & 1 & 0.174 \\
\hline \multirow{5}{*}{ Matrix of general academic staff } & & $\mathrm{A}$ & $\mathrm{B}$ & $\mathrm{C}$ & $\mathrm{D}$ & Eigen vector & Product \\
\hline & ST1 & 0.192 & 0.208 & 0.502 & 0.455 & 0.117 & 0.395 \\
\hline & ST2 & 0.092 & 0.095 & 0.117 & 0.275 & 0.163 & 0.176 \\
\hline & ST3 & 0.616 & 0.594 & 0.227 & 0.096 & 0.292 & 0.262 \\
\hline & ST4 & 0.100 & 0.103 & 0.154 & 0.174 & 0.428 & 0.145 \\
\hline
\end{tabular}

\section{Comparison of the Physical and Technical Infrastructure Factors and the Strategies}

The comparison of the A, B, C, D sub-factors within the Physical and Technical Infrastructure factor has been given in Figure 9. According to Figure 9, C (Elimination of the shortage of building for the department of Urban and Regional Planning) was determined as the most appropriate sub-factor with 0.420 value. D (Creation of the possibility of archiving in digital and physical media and creation of database in the faculty) was determined as the second most appropriate sub-factor with 0.334 value.

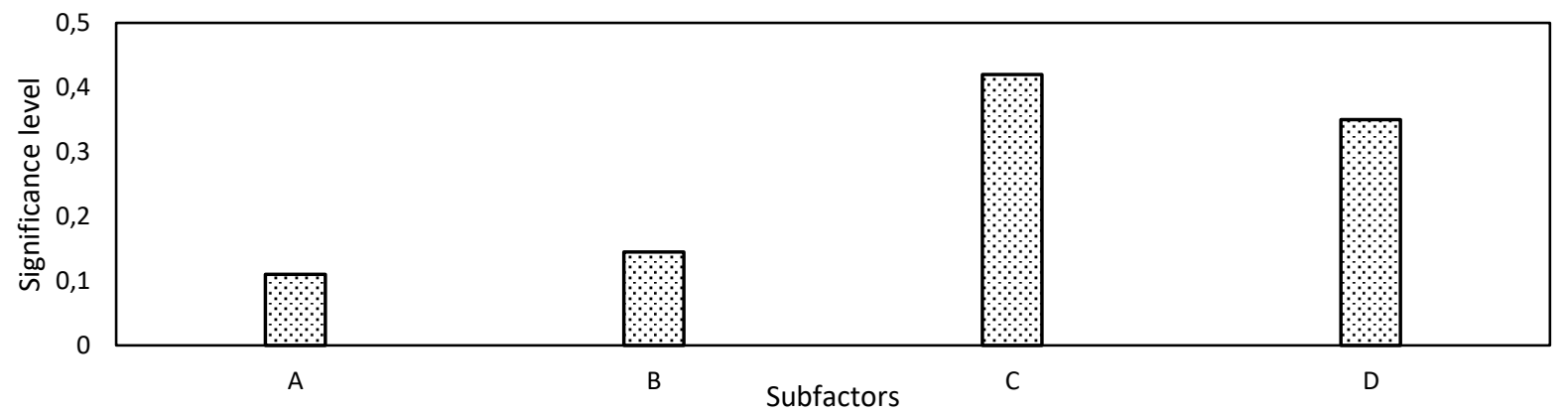

Figure 9. The comparison of the $A, B, C, D$ sub-factors within the Physical and Technical Infrastructure factor 
Given the statistical values in Table 10, the participants were asked which strategy was more appropriate for the provision of workshop spaces for student design studies within the faculty (A). The most appropriate strategy was ST4 (elimination of all deficiencies in the physical environment) with a value of 0.599 .

Table 10

Comparison of physical and technical infrastructure factors and strategies

\begin{tabular}{|c|c|c|c|c|c|c|c|}
\hline \multirow{5}{*}{\multicolumn{2}{|c|}{$\begin{array}{l}\text { Matrix of physical and technical } \\
\text { infrastructure sub-factors }\end{array}$}} & & A & B & C & $\mathrm{D}$ & $\mu$ \\
\hline & & A & 1 & 2 & 4 & 2 & 0.108 \\
\hline & & B & & 1 & 4 & 3 & 0.138 \\
\hline & & $\mathrm{C}$ & & & 1 & 2 & 0.420 \\
\hline & & $\mathrm{D}$ & & & & 1 & 0.334 \\
\hline \multirow{5}{*}{\multicolumn{2}{|c|}{ Matrix of strategies according to $A$}} & & ST1 & ST2 & ST3 & ST4 & \\
\hline & & ST1 & 1 & 0.5 & 0.5 & 5 & 0.180 \\
\hline & & ST2 & & 1 & 0.5 & 4 & 0.133 \\
\hline & & ST3 & & & 1 & 5 & 0.088 \\
\hline & & ST4 & & & & 1 & 0.599 \\
\hline \multirow{4}{*}{\multicolumn{2}{|c|}{ Matrix of strategies according to $B$}} & ST1 & 1 & 0.333 & 0.333 & 5 & 0.214 \\
\hline & & ST2 & & 1 & 1 & 4 & 0.097 \\
\hline & & ST3 & & & 1 & 5 & 0.090 \\
\hline & & ST4 & & & & 1 & 0.598 \\
\hline \multirow{4}{*}{\multicolumn{2}{|c|}{ Matrix of strategies according to $C$}} & ST1 & 1 & 0.5 & 1 & 4 & 0.162 \\
\hline & & ST2 & & 1 & 1 & 5 & 0.108 \\
\hline & & ST3 & & & 1 & 5 & 0.128 \\
\hline & & ST4 & & & & 1 & 0.601 \\
\hline \multirow{4}{*}{\multicolumn{2}{|c|}{ Matrix of strategies according to $D$}} & ST1 & 1 & 0.2 & 0.333 & 3 & 0.285 \\
\hline & & ST2 & & 1 & 1 & 5 & 0.084 \\
\hline & & ST3 & & & 1 & 4 & 0.099 \\
\hline & & ST4 & & & & 1 & 0.532 \\
\hline \multirow{5}{*}{$\begin{array}{l}\text { Matrix of general physical and } \\
\text { technical infrastructure }\end{array}$} & & $\mathrm{A}$ & B & C & $\mathrm{D}$ & Eigen vector & Product \\
\hline & ST1 & 0.180 & 0.214 & 0.162 & 0.285 & 0.108 & 0.285 \\
\hline & ST2 & 0.133 & 0.097 & 0.108 & 0.084 & 0.138 & 0.084 \\
\hline & ST3 & 0.088 & 0.090 & 0.128 & 0.099 & 0.420 & 0.099 \\
\hline & ST4 & 0.599 & 0.598 & 0.601 & 0.532 & 0.334 & 0.532 \\
\hline
\end{tabular}

According to the sub-factor of updating the general equipment required for a modern educational environment (B), ST4 (elimination of all deficiencies in the physical environment) was determined to be the most appropriate strategy with a value of 0.598 . According to the sub-factor of eliminating the building deficiency for the department of urban and regional planning, ST4 (elimination of all deficiencies in the physical environment) was determined to be the most appropriate strategy with a value of 0.601 . According to the sub-factor of creating opportunities to archive in the digital and physical environment and create database in the faculty, ST4 (elimination of all deficiencies in physical environment) was determined as the most appropriate strategy with a value of 0.532 . As a result of comparing the physical and technical infrastructure factors, the most appropriate strategy was determined as ST4 (elimination of all deficiencies in the physical environment) with 0.575 .

\section{Comparison of All Infrastructure Factors with Each Other and with Strategies}

Values obtained from the sub-factors of education, corporate structure, academic staff, and physical and technical infrastructure in determining the most appropriate strategy for the Faculty of Architecture Strategic Plan were found by the multiplication of evaluation matrix obtained from the comparison of four main factors with each other. The result obtained can be seen in Figure 10. 


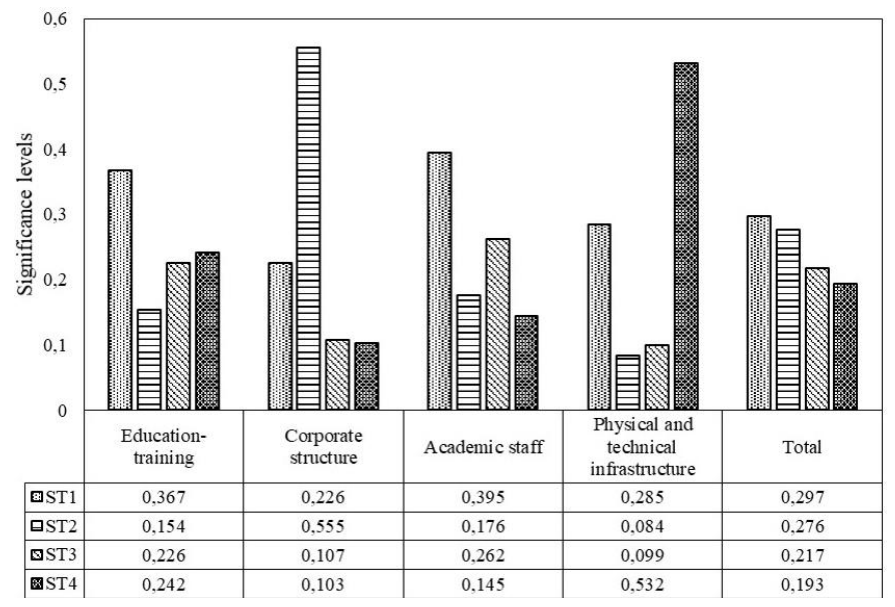

Figure 10. The results of the comparison of four main factors

As a result of comparing all the factors with each other and evaluating these factors according to the strategies, the most appropriate strategy for the Faculty of Architecture Strategic Plan has been determined as ST1 (Planned development of the education program) with a value of 0.297 . ST2 (Increasing the number of national and international research and projects) is the second most appropriate with a value of 0.276 , ST3 (increasing the number of academic staff) is the third most appropriate with a value of 0.217 and ST4 (Eliminating all the deficiencies in the physical environment) is the fourth most appropriate strategy with a value of 0.193 .

\section{CONCLUSIONS}

This study proposes a strategic plan for the Faculty of Architecture of Karadeniz Technical University. In order to prepare this plan, firstly the current state of the faculty was taken into consideration and SWOT analysis was carried out. The results of the SWOT analysis revealed that strengths and weaknesses, opportunities and threats were identified and presented on a table in the context of education, corporate structure, academic staff, and physical and technical infrastructure main factors. To decide on the strategies, the TOWS matrix was constructed taking into account the results of the SWOT analysis, and 4 strategies were determined based on SWOT analysis and TOWS matrix results. These are ST1. Planned development of the education program, ST2.Increasing the number of national and international research and projects, ST3. Increasing the number of academic staff and ST4. Elimination of all deficiencies in the physical environment. SWOT analysis technique was used while making strategic planning (Grasseova, et al., 2010; Dyson, et al.,1998). In addition, the TOWS matrix is arranged (Dyson, et al.,2004). Strategies were determined with these techniques. A survey was conducted with 18 instructors for the determined strategies. The survey results were evaluated by using the AHS-fuzzy set technique. The results of the evaluations indicated that strategies according to their significance levels are ST1. Planned development of the education program, ST2. Increasing the number of national and international research and projects, ST3. Increasing the number of academic staff and ST4.Elimination of all the deficiencies in the physical environment with 0.361 value. ST1 differed from ST2 by $2 \%$, from ST3 by $8 \%$ and from ST4 by $10 \%$ in terms of significance levels. Figure 11 demonstrates the percentage differences in significance levels of the strategies. 


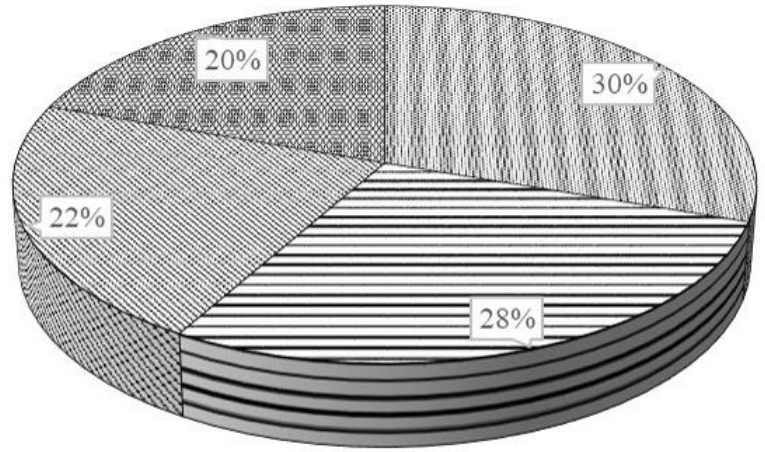

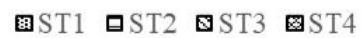

Figure 11. The percentage differences in significance levels of the strategies

Thanks to the strategies and significance levels determined at the end of the study, the steps to be taken for the future have been identified. Strategic planning has a crucial role to be able to walk with more confident steps to the future and to ensure that the institution improves according to its mission and vision. We realized a pilot study that demonstrates the importance of strategic planning. It is crucial that such strategic planning studies are carried out in all the architectural faculties in Turkey, and the differences among universities are identified and analysed. Thus, the differences among the institutions providing the same education can be determined to eliminate the deficiencies and the imbalances among the institutions can be removed.

\section{ACKNOWLEDGEMENTS}

We would like to thank Dilek Şen Beyazlı, Muteber Erbay and Handan Hacımehmetoğlu for their support in obtaining the necessary data for the study.

\section{KAYNAKÇA}

Alford, B.D, Golden B. (2004). Two Application Involving the Analytic Hierarcy Process, MSc Thesis, University of Maryland.

Allison, M., Kaye, J. (2015). Strategic Planning for Non-profit Organizations: A Practical Guide for Dynamic Times, Third Edition, Wiley Press, New Jersey.

Aydemir, B., Düzyol, C. ve Usta, E. (2003). Kamu Kuruluşları İ̧̧in Stratejik Planlama Kılavuzu, T.C. Başbakanlık Devlet Planlama Teşkilatı (DPT)

[http://www.ktu.edu.tr/fakulte/mmf/turkce/spc/DPT.pdf] Erişim Tarihi (12.12.2016).

Dyson, R.G., O Brien, F.A. (1998). Strategic Development: Methods and Models. Wiley, Chichester.

Fine, L.G. (2010). The SWOT Analysis, Create Space Independent Publishing Platform; 1 edition, Canada. Ho, W.(2008). Integrated Analytic Hierarchy Process and it's Applications-A Literature Review, European Journal of Operation Research (186) 211-228.

Kangas, J., Kurtilla, M., Kajanus, M. and Kangas, A. (2003). Evaluating the Management Strategies of a Forestland Estatethe S-O-S Approach, Journal of Environmental Management (69) 349-358.

Mc Cune, S.(1986). Guide To Strategic Planning For Educators, Alexandria, VA, ASCD.

Mimarlık Fakülte Binası Fotoğrafı [http://www.ktu.edu.tr/icmimarlik] Erişim Tarihi (21.12.2016). 


\section{Yaşar, Maçka Kalfa, Pirselimoğlu Batman \& Sümer Haydaraslan / Developing the Strategic Plans}

Dyson, R.G. (2004). Strategic development and SWOT analysis at the University of Warwick, European Journal of Operational Research, (152) 631-640.

Saaty, T.L (1980). The Analytic Hierarchy Process: Planning, Priority Setting, Resource Allocation (Decision Making Series), McGraw-Hill, USA.

Shretha, R.K., ALAVALAPATI, J. R.R. and KALMBACHER, R. S. (2004) Exploring the Potential for Silvopasture Adoption in South-central Florida: An Application of SWOT-AHP Method, Agricultural Systems (81) 185-199.

Steiner, G.A. (1989). Strategic Planning: What Every Manager Must Know. Free Press, New York.

Weihrich, H. (1982). The TOWS matrix: A tool for situational analysis. Long Range Planning 15 (2), 54-66. 